\title{
CHARACTERIZATION OF A NATURAL FOCUS OF PUUMALA HANTAVIRUS INFECTION IN THE CZECH REPUBLIC
}

\author{
Milan Pejčoch ${ }^{1}$, J iří Unar2, Bohumír Křižzi ${ }^{1,5}$, Eva Pauchová3, Roman Rose \\ ${ }^{1}$ National Institute of Public Health, Prague, Czech Republic \\ ${ }^{2}$ Department of Botany, Faculty of Sciences, Masaryk University, Brno, Czech Republic \\ ${ }^{3}$ District Hospital, Prachatice, Czech Republic \\ ${ }^{4}$ National Park Š umava, Vimperk, Czech Republic \\ ${ }^{5}$ Charles University, $3^{\text {rd }}$ Medical Faculty, Prague, Czech Republic
}

\begin{abstract}
SUMMARY
Hantaviruses are RNA viruses of the Bunyaviridae family, represented in the Czech Republic by three genospecies: Dobrava-Belgrade, Puumala and Tula. They persist in natural foci of infection. In 2004 to 2009, a local outbreak with 18 reported cases of nephropathia epidemica caused by Puumala hantavirus occurred in the Šumava mountains and foothills and was spacially associated with another outbreak in Lower Bavaria, Germany. In the J elení locality in the Šumava mountains at $880 \mathrm{~m}$ above sea level, we identified a natural focus of infection suspected to be the source of hantavirus infection in forest workers. The focus was characterized geobotanically as a montane mixed forest with the predominance of beeches within the association Dentario enneaphylli-F agetum, alliance Fagion, sub-alliance Eu-Fagenion, in a cold climate region with a podzolic soil. The biocenoses where hantaviruses are circulating typically show higher microclimate humidity. Their characteristization can be helpful in predicting where hantaviruses are likely to circulate.
\end{abstract}

Key words: hantavirus, Puumala, biocenosis, Myodes glareolus

Address for correspondence: B. Kříž, National Institute of Public Health, Šrobárova 48, CZ 10048 Prague, Czech Republic.

E-mail: bohukriz@szu.cz

\section{INTRODUCTION}

Hantaviruses are RNA viruses of the Bunyaviridae family. The virion contains negative single stranded RNA divided into three segments. Hantaviruses have been described relatively recently, in 1978 (1). From the ecological point of view, these viruses are so called roboviruses, i.e. viruses transmitted by rodents. In the nature, they are circulating among their hosts, independently from humans, in natural foci of non-vector-borne infection. Currently several dozens of distinct hantavirus genospecies have been known. Each hantavirus species has a specific rodent or insectivore host in which it causes persistent infection. Humans are infected accidentally by contaminated excreta from these hosts while entering the natural focus of infection or as a result of another contact with the causative agent. In Central Europe the following four hantavirus genospecies are circulating in the nature: Dobrava-Belgrade (DOB), among yellow-necked field mice (Apodemus flavicollis), Puumala (PUU), among bank voles (Myodes glareolus), Tula (TUL), among common voles (Microtus arvalis), and Saaremaa (SAA) among black-striped field mice (Apodemus agrarius). In the Czech Republic the first three genospecies were established. Humans can be infected by any of these viruses, but the DOB infection is the most severe, while TUL is considered as non-pathogenic, although it has also been reported to cause infection in humans (2). A serosurvey in a sample of adults from the Czech Republic revealed the presence of anti-hantavirus antibodies in $1.66 \%$ of the screened subjects (3).
In 2004, the first cases were reported in occupationally exposed forest workers in the Prachatice region. A small local outbreak was observed with 18 cases that differed in the severity of symptoms and five positives were detected by the screening (4). This outbreak was geographically associated with a similar one in Lower Bavaria, Germany.

We attempted to identify the natural focus where some patients might have acquired infection. Our decision was based on assumption that the PUU virus natural host is the bank vole that lives in woodland areas with deciduous trees. We decided to capture rodents in the suspected localities to analyze them in the laboratory. The locality where the PUUV antigen was detected in the lungs of bank voles was geobotanically characterized in detail.

\section{MATERIAL AND METHODS}

After identifying the localities suspected to be the source of infection, we captured the rodents. The suspected area was situated at the fringe of a Šumava commune called Jelení, an administrative part of the village Nová Pec in the district Prachatice: GPS coordinates $48^{\circ} 49^{\prime} 34^{\prime \prime N} 13^{\circ} 52^{\prime} 16^{\prime \prime} \mathrm{E}$. The altitude was about $900 \mathrm{~m}$ above sea level.

The animals were captured by snap-trapping or live-trapping. They were euthanized when needed and dissected. As the outbreak was caused by the genospecies Puumala whose hosts in the nature are bank voles, these rodents were the target animals to trap. The 
harvested lungs were stored in cold conditions, then frozen in the laboratory and homogenized in a small amount of saline to be screened for the presence of the hantavirus antigen by the ELISA HANTAGNOST kit from the Chumakov Institute of Poliomyelitis and Viral Encephalitides, Academy of Medical Sciences Moscow, Russia. The locality where the hantavirus antigen was identified in the bank vole lungs was characterized geobotanically in detail directly in the field.

\section{RESULTS}

In 2005 through 2009, six one-week field expeditions to the selected area were conducted, three in each spring and autumn. Altogether 85 rodents of four species were captured, with 41 of them being the target animals bank voles (Myodes glareolus) (Table 1).

The lungs of all captured animals were screened by ELISA for the presence of the hantavirus antigen. Two bank voles tested positive. They were captured on September 30, 2008 in the locality Jelení - Medvědí cesta (Bear path): coordinates 4849’32”N a $13^{\circ} 52^{\prime} 15^{\prime} \mathrm{E}$, at an altitude of about $900 \mathrm{~m}$ above sea level.

The two positive samples were further analyzed by molecular genetic methods to be classified, based on the nucleotide sequence of the hantavirus L RNA segment, into the Puumala genospecies (Fig. 1).

Table 1. Captured rodent species

\begin{tabular}{|l|c|}
\hline Species & Number \\
\hline Myodes glareolus & 41 \\
\hline Apodemus flavicollis & 29 \\
\hline Apodemus sylvaticus & 12 \\
\hline Microtus agrestis & 3 \\
\hline Total & 85 \\
\hline
\end{tabular}

\section{Geobotanical characterization}

The locality Jelení - Bear path is situated in the Šumava mountains, on the southwestern slope of the Jelenská mountain, directly below the Bear path, at about $1 \mathrm{~km}$ south of the site where the last bear in the Šumava mountains was shot dead. The locality coordinates are as follows: $48^{\circ} 49^{\prime} 32^{\prime \prime} \mathrm{N}$ and $13^{\circ} 52^{\prime} 15^{\prime \prime} \mathrm{E}$. The altitude is about $900 \mathrm{~m}$ above sea level (Fig. 2).

Orographically, this area belongs to the Pleš highlands which are the highest part of the Trojmezenská highlands. Podzolic soil is the prevailing soil type in the area $(5,6)$. Quitt considers the area as a cold climate region (7). The factors such as the geological background, terrain morphology, soil conditions, local macroclimate and microclimate influence the vegetation cover in it. Natural disasters such as hurricane Kyrill that had an impact on the area are also relevant.

The locality Bear path is covered by partly sparsed montane mixed forest with the predominance of Fagus sylvatica that can be classified into the association Dentario enneaphylli-Fagetum Oberdorfer ex W. et A. Matuszkiewicz 1960 of the alliance Fagion Lunquet 1926 and suballiance Eu-Fagenion Oberdorfer 1957 em.

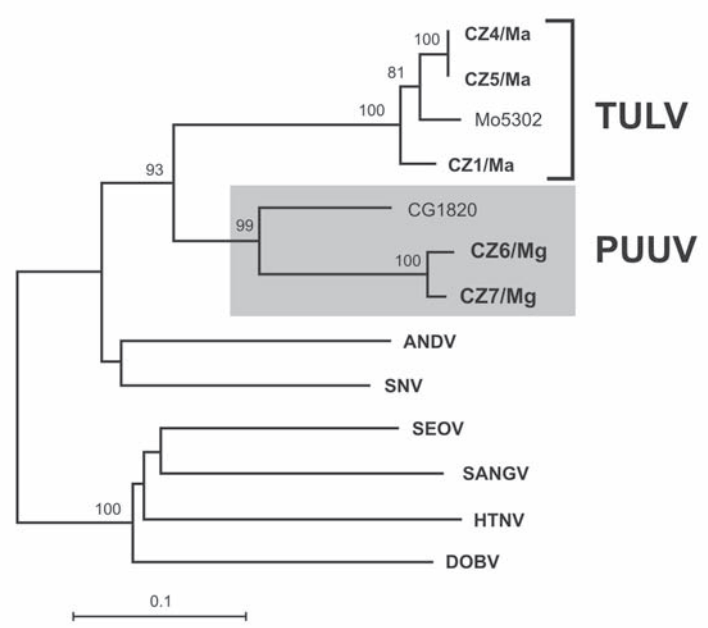

Fig. 1. Neighbor-Joining phylogenetic tree of hantaviruses showing the phylogenetic placement of CZ6/Mg and CZ7/Mg seguences found in Myodes glareolus animals trapped in the Sumava Mountain (indicated by bold face). The tree was computed with the MEGA4 package by using the evolutionary distances calculated with Maximum Composite Likelihood method. The values at the tree branches are the bootstrap support values (1000 replicates). The scale bar indicates an evolutionary distance of 0.1 substitutions per position in the sequence. TULV, Tula virus; PUUV, Puumala virus; DOBV, Dobrava-Belgrade virus; SANGV, Sangassou virus; HTNV, Hantaan virus; SEOV, Seoul virus; SNV, Sin Nombre virus, ANDV, Andes virus.

Tüxen in Oberdorfer et Tüxen 1958. It is also documented by the following phytocenological picture taken on May 18, 2009.

Aspect: north-western, slope: $25^{\circ}$.

Total coverage: 90\%, $\mathrm{E}_{3}: 70 \%$, E2: 10\%, E1: 50\%.

$\mathrm{E}_{3}$ : Fagus sylvatica 3, Picea abies 2, Abies alba 2, Acer pseudoplatanus + .

$\mathrm{E}_{2}$ : Fagus sylvatica 1, Picea abies 1, Sorbus aucuparia 1, Abies alba 1 , Acer pseudoplatanus + .

$\mathrm{E}_{1}$ : Oxalis acetosella 3, Calamagrostis villosa 2, Myosoton aquaticum 2, Dryopteris dilatata 1, Athyrium filix-femina 1, Gymnocarpium dryopteris 1, Milium effusum 1, Festuca altissima 1, Prenanthes purpurea 1, Myosotis sylvatica 1, Mycelis muralis 1, Galeobdolon montanum 1, Moehringia trinervia 1, Vaccinium myrtillus 1, Dryopteris filix-mas + , Hieracium murorum + , Avenella flexuosa + , Geranium robertianum + , Luzula sylvatica + , Maianthemum bifolium +, Homogyne alpina +, Actaea spicata + , Galium odoratum +.

The found small mammals were, in addition to Myodes glareolus, Apodemus flavicollis, Apodemus sylvaticus, Microtus agrestis and Sorex araneus. The last two ones were captured in humid areas.

\section{DISCUSSION}

Since hantaviruses are found in specific natural environments, we first attempted to identify the natural focus of infection where hantaviruses are circulating among their reservoir hosts. The following step was the geobotanical characterization of this natural focus of infection. The causative agent was Puumala virus 


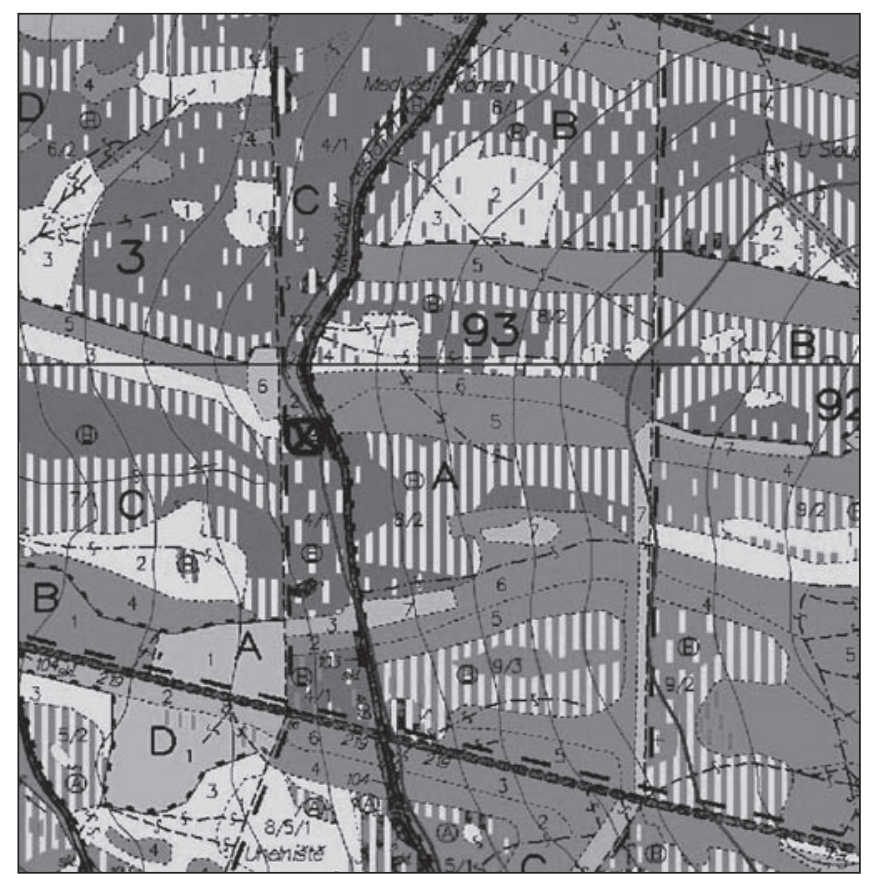

Fig. 2. Vegetation ground cover of area Stozec, Jelení - Bear path. In this locality (+) 41 bank voles were captured. Two of them (4.9\%) were Puumala virus positive.

(PUUV) that is circulating among bank voles (Myodes glareolus) in natural foci of non-vector-borne infection. The habitat therefore needs to be suitable for bank voles to live in. In the Czech Republic, these rodents are found in forest areas with a specific geobotanical structure. Nevertheless, in the European literature, the biocenotic data on natural foci of hantavirus infection are scarce. Most studies only take into consideration the effect of climate change on the distribution of hantaviruses $(8,9,10)$.

The most detailed biocenotic data are available from Belgium (11), Slovakia (12) and the Czech Republic (13). Other authors only specify the forest type, e.g. beech woodland (14). Furthermore, the earlier biocenological data do not distinguish between hantavirus genospecies. The biotopes where different hantaviruses are circulating differ according to the requirements of their reservoir hosts. From our previous studies it follows that hantaviruses may not circulate in all populations of their potential hosts. Other factors such as the biotope microclimate conditions also seem to play a role in the circulation of hantaviruses. Another factor is soil humidity and, consequently, relative air humidity in the herbaceous ground cover. In previous study we identified an indicator xerophytic plant-Arabidopsis thaliana whose presence correlated with hantavirus antigen negativity in the lungs of common voles captured in the South Moravia area (13).

On the other hand, in the Jelení - Bear path locality, the presence of the Puumala hantavirus was detected in a wetland biotope. At about $150 \mathrm{~m}$ from this site above the Bear path, a population of hantavirus-free bank voles was found in a zone between a clearing left by the hurricane Kyrill and a young small pole stage mixed beech/spruce stand. This locality appears to be relatively drier since allowing more sunlight and wind to penetrate to the ground storeys. In comparison with the above-mentioned vegetation, the herbaceous storey contains less Oxalis acetosella and Calamagrostis villosa, but higher proportions of Avenella flexuosa and Maianthemum bifolium. Similar results have been reported by (15). Increased numbers of PUUV-infected bank voles were observed in moist forests with Alectoria spp., Picea abies, fallen wood, and Vaccinium myrtillus, that can be considered as suitable indicator species.

We attempted to characterize geobiocenotically a natural focus of Puumala virus infection. The results might contribute to the identification of the biocenotic predictors of the circulation of hantaviruses among the specific hosts.

Above mentioned locality is a part of popular summer tourism area therefore the risk of infection of visitors cannot be ruled out (16).

\section{Acknowledgements}

This research was supported by grants No. NR 9420-3/2007 of the Grant Agency of the Ministry of Health of the Czech Republic.

The authors thank Dr.Boris Klempa,PhD, and Lukas Radosa for valuable help in sequencing of the Puumala viruses and laboratory technicians Eva Pěkná and Pavlína Klapušová for excellent technical assistance.

\section{REFERENCES}

1. Lee HW, Lee PW, Johnson KM. Isolation of the etiologic agent of Korean Hemorrhagic fever. J Infect Dis.1978 Mar;137(3):298-308.

2. Klempa B, Meisel H, Räth S, Bartel J, Ulrich R, Krüger DH. Occurrence of renal and pulmonary syndrome in a region of northeast Germany where Tula hantavirus circulates. J Clin Microbiol. 2003 Oct;41(10):4894-7.

3. Vacková M, Beran J, Douda P, Soukup J. Epidemiologic problems in hantavirus infections. Epidemiol Mikrobiol Imunol. 2000 Feb;49(1):11-5. (In Czech.)

4. Křŕž B, Pejčoch M, Pauchová E, Malý M. Local outbreak of nephropatia epidemica in the Czech Republic. Epidemiol Mikrobiol Imunol. Forthcoming 2010.

5. Albrecht J, editor. Českobudějovicko. In: Mackovčin P, Sedláček M, editors. Protected areas of the Czech Republic. Vol. VIII. Brno: EkoCentrum; 2003. (In Czech.)

6. Demek J, Mackovčin P, editors. Mountains and lowlands: geographical lexicon of the Czech Republic. Brno: AOPK; 2006. (In Czech.)

7. Quitt, E. Map of climatic regions of the Czechoslovak Socialist Republic. Prague: Kartografické nakladatelství;1970. (In Czech.)

8. Clement J, Vercauteren J, Verstraeten WW, Ducoffre G, Barrios JM, Vandamme AM, et al. Relating increasing hantavirus incidences to the changing climate: the mast connection. Int J Health Geogr. 2009 Jan 16;8:1.

9. Klempa, B. Hantaviruses and climate change. Clin Microbiol Infect. 2009 Jun;15(6):518-23.

10. Menne B, Ebi KL, editors. Climate change and adaptation strategies for human health. Darmstadt: Steinkopff; 2006.

11. Verhagen R, Van der Groen G, Ivanov A, Van Rompaey J, Leirs H, Verheyen W. Occurrence and distribution of Hantavirus in wild living mammals in Belgium. Acta Virol. 1987 Jan;31(1):43-52.

12. Grešíková M, Bilčíková M, Bilčík P, Černý V, Daniel M, Havlíková G, et al. Hemorrhagic fever with renal syndrome. Bratislava: Veda; 1988. (In Slovak.)

13. Unar J, Daneš L, Pejčoch M. The basic ecology and vegetation characteristic of the natural foci of hantaviruses in South Moravia. In: Reports of Museum of National History and Arts in Olomouc. Science no. 273/1996. Olomouc: Vlastivědné muzeum; 1996. p. 19-55.

14. Pilaski J, Ellerich C, Kreutzer T, Benik W, Lewandowski B, Lang A, et al. Endemic occurrence of hemorrhagic fever with renal syndrome in the Federal Republic of Germany. Z Arztl Fortbild (Jena). 1991 Sep 25;85(18):869-74. (In German.)

15. Olsson GE, White N, Hjältén J, Ahlm C. Habitat factors associated with bank voles (Clethrionomys glareolus) and concomitant hantavirus in northern Sweden. Vector Borne Zoonotic Dis. 2005;5(4):315-23.

16. Vacková M, Douda P, Beran J, Gál P, Radovnický V. Serologic detection of hantavirus antibodies. Epidemiol Mikrobiol Imunol. 2002 Apr;51(2):74-7. (In Czech.). 